\title{
811.163.41'282.2(497.11-14)
}

811.163.41'342.8

https://doi.org/10.18485/sj.2019.24.1.43

ЂОРЂЕ М. ГЕНОВИТ

Универзитет у Београду

Филолошки факултет
Оригинални научни рад

Примљен: 11. 09. 2018.

Прихваћен: 15. 01. 2019.

\section{ОСНОВНЕ АКЦЕНАТСКЕ ОСОБИНЕ ГОВОРА СЕЛА ВИЧЕ}

У раду се даје преглед најважнијих акценатских особина села Виче (Драгачево) на основу анализираног аудио-снимка аутентичног говорника са поменутог подручја. Након увода, у коме се представљају географски положај, досадашња етнолошка и лингвистичка испитивања датог терена и циљеви истраживања, говор се на основу акценатских параметара локализује на дијалекатској мапи српског језика, уз ослањање на досадашњу литературу. Поред основних црта, које упућују да је реч о једном од говора источнохерцеговачког типа у Србији (четвороакценатски систем са постакценатским дужинама, преношење акцента на проклитику), скреће се пажња и на неке од специфичности које овај идиом приближавају шумадијско-војвођанском говорном типу (губљење постакценатских дужина, недоследно преношење на проклитику). Међу специфичне акценатске црте убраја се и метатаксичко преношење акцента са ултиме на пенултиму, настало као новији нанос из шумадијско-војвођанских говора који се наслањају на косовско-ресавске идиоме, чиме се вички (али и уопште драгачевски) говор приближава говорним типовима са старијом акцентуацијом. На овај начин отвара се и питање алотоничности пренесеног кратког акцента. Узете скупа, наведене чињенице потврђују да говор Виче базично припада источнохерцеговачком го-

"genovic94@gmail.com

** Овај рад представља краћу верзију рада који је добио награду „Др Петар Ђукановић” за најбољи семинарски рад из Дијалектологије српског језика на Филолошком факултету у Београду у школској 2015/2016. години. 
ворном типу, али да се у њега, посредством више фактора, инфилтрирају многе иновационе црте, што захтева праћење његовог даљег развитка.

Кључне речи: Вича, Драгачево, дијалектологија, источнохерцеговачки, акценатски систем, метатаксичко преношење.

1. Увод. Село Вича је насеље које се налази у општини Лучани, административном центру области која се назива и Драгачево. Ова регија у (југо) западној Србији, данас део Моравичког округа (са центром у Чачку), некада је чинила тзв. драгачевски срез, али је доцније одређени број места, са променом система територијалне организације, распоређен у друге срезове, понајвише у Ариљски и Пожешки. Ипак, већина становника, нарочито старијих, и даље Драгачево види као целину, иако је оно што се данас назива тим именом само део некада знатно веће територије. Што се самог села Виче тиче, оно се налази у источнијем делу Драгачева, тзв. Горњем Драгачеву. Окружено је Горачићима и Губеревцима са северне стране; Ртима, Пшаником и Котражом са западне; Каоном и Милатовићима са источне стране. Са селима Вучковица и Доњи Дубац граничи се линијом запад - исток на јужној страни. Попут читавог Драгачева, и Вича се налази на брдовитом терену, на обронцима планине Јелице.

Почетком прошлога века, Вича је спадала у највеће насеобине у целом Драгачеву, а у Горњем је важила и за највећу (Јовановић 1908: 401). Према наводима више истраживача који су се кретали Драгачевом, овде се могу наћи остаци старине који упућују на то да је место могло бити насељено и у току средњег века, за време тада моћне српске државе, о чему податке даје ономастика, али и народно предање (Јовановић 1908: 407). Ипак, први поуздан податак о самом имену места јавља се тек у XIX веку ${ }^{1}$.

Као и читава регија, и Вича је, судећи по подацима које доносе истраживачи овог поднебља (в. Ердељановић 1902, Јовановић 1908, Ђукановић 1995) и народно предање, на више махова плављена динарском метанастазичком струјом². Стариначки слој становништва, иако је морао постојати (узимајући у обзир захвалне особине терена), вероватно је већ при првом доласку досељеника био знатно ослабљен, о чему се највише може закључити на основу језичких испитивања овог краја. Наиме, будући да говор Драгачева у својој суштини показује континуитет са околним говорима источнохерцеговачког

${ }^{1}$ Иако постоје назнаке да први помени места сежу у XV век, село се под овим именом помиње у попису из 1818. године. Међутим, у једном писму из 1815. године, у ком Милош Обреновић поставља Сима Радовића за капетана ових крајева, поред осталих места којима ће овај управљати (Губеревци, Живица, Каона...), наводи се и Винча (Јовановић 1908: 355-356).

${ }^{2}$ Коста Јовановић наводи тачне податке за Горње Драгачево који се односе на број породица (укупно 190, од чега 150 досељеничких), као и на области из којих су се оне доселиле: Стари Влах 38, Сјеница 38, Стара Србија 19, Херцеговина 6, Црна Гора 9, Чачански и Ужички округ 30, околина Нове Вароши до Лима 2, остало 2. (Јовановић 1908: 359-361). 
типа у Србији, јасно је како није могло бити ни већег утицаја старинаца на досељенички идиом. Ову претпоставку, на најнепосреднији начин, потврдила је и монографија „Говор Драгачева” Петра Ђукановића, која се посебно бавила говором овог краја. Управо на њу наслањаће се и овај рад, који за циљ има описивање прозодијског (тј. акценатског) система говора села Виче. Притом највећи нагласак у овом случају ће бити стављен на скицирање општих акценатских одлика вичког (и уопште драгачевског) идиома, али и на неке специфичности које га одвајају од њему суседних говора. Ту се, пре свега, мисли на поједина одступања од новије штокавске акцентуације у вишесложним (највише двосложним) речима, које су у ранијем ступњу развоја имале кратак силазни акценат на ултими и, супротно очекиваном краткоузлазном акценту на пенултими, добиле на истом месту поново краткосилазни акценат, као и на тенденцију губљења постакценатских дужина. На овај начин створиће се услови за прецизно лоцирање овог идиома на дијалекатској карти српског језика, а уједно и за потврду или модификацију ставова који су раније изношени поводом истог питања.

Грађа коришћена при испитивању искључиво је црпена из разговора са информатором Велибором Пајићем (1937-2018), рођеним у Вичи (у Ракића засеоку, на Пајића коси) $)^{4}$. Разговор је вођен крајем 2015. године, а стицај околности је условио да то буде и једини разговор. Будући да је информатор готово читав живот провео у месту рођења, сматрамо да је његов говор у великој мери нетакнут утицајима са стране (колико је то у највећој мери било могуће), те да као такав представља веродостојан и типичан узорак са терена. Ипак, тренутна ограниченост материјала и простора донекле ће условити природу овог рада.

2. Акценти и њихова дистрибуција. Судећи на основу материјала, говор Виче припада штокавском дијалекту, прелазног ијекавско-екавског наречја источнохереговачког говорног типа. На то веома добро упућује поменута замена старога гласа Ђ, који даје двојаке рефлексе (в. нпр. однос снијег < снъг, али месечина $<$ мъсечина $)^{5}$, а још више и сама акцентуација. Говор овог села, као уосталом и читавог Драгачева ${ }^{6}$, поседује сва четири акцента позната стан-

${ }^{3}$ В. о томе синтезе попут Ивић 2001 (в. мапу дијалеката), Пецо일 1980, али и монографије о оближњим говорима, нпр. Марковић 2011.

${ }^{4}$ Па̀јићи спадају у једну од најстаријих драгачевских породица. У Јовановић 1908: 44 се наводи да су Пајићи поред Маричића једна од две стариначке породице, мада то није у потпуности тачан податак. По најновијим подацима (родослов породице Пајић) обе ове породице доселиле су се у првом таласу, негде почетком XVIII в.

${ }^{5}$ Углавном је ъ $\rightarrow$ е када се налази под акцентом, међутим, у случајевима када се налази ван акцента, јат има јекавски рефлекс (уп. пуно̀љетна $<$ пуно̀льтна). Истина, постоје примери у којима се ъ под акцентом изговара као јекавско (нпр. дјѐце̄).

${ }^{6}$ Ђукановић 1995: 88. 
дардном српском језику, различита по квантитету и квалитету: Гр̈аб, ра̀кија, са̂m, Ча́чак; мӧкра, пѐтљали, не̂ма, че́за.

Ови акценти дистрибуирају се у великом броју случајева као и у стандардном српском језику. То значи да се силазни акценти (и дуги и кратки) могу налазити само на почетку речи (уп. нпр. Јёлица, гӧдина, овъце, сйђем, али не и отёрамо, седиิм), те да тако једино они могу бити присутни у једносложним речима ( $p a ̈ m, ~ с в е ̈, ~ \partial \hat{н}, c \hat{a m}$ ), а да се узлазни акценти могу наћи на свим слоговима у речи осим последњег (нпр. во̀лови, хармо̀ника, Чáчак, обна́родујеш, neдuте́p $\bar{a})^{7}$. Сходно томе, узлазни акценти не могу се наћи у једносложним речима (мада се наилази на пример би́л, настао од редукције у би́ли). Вички

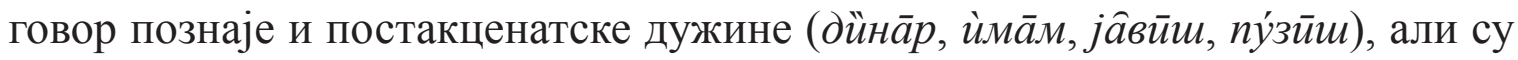
се из њега, због метатонијског преношења, изгубили сви некада дуги слогови пред нагласком - они су у том процесу замењени дугоузлазним акцентом (в. нпр. имп. па́мти < па̄мтй, Нмн. с.р. пре́ла < прёлӓ или бо́лница < бо̄лнйц̧а).

2.1. Метатаксичко преношење кратког акцента са ултиме на пенултиму. Међутим, иако је ситуација готово идентична као и у великом броју новоштокавских говора новије акцентуације (а самим тим и стандардном језику), у говору Виче наилазимо на једну појаву која је већини горе поменутих идиома страна. На њу је при детаљном опису целокупног драгачевског говора наишао и Петар Ђукановић, па стога сматрамо да би било корисно детаљније се осврнути на њу овом приликом. Наиме, као што је у уводу напоменуто, ради се о преношењу кратког силазног акцента са ултиме на претходни слог у двосложним и неким вишесложним речима. Тако ће се у тим речима уместо очекиваног пренесеног краткоузлазног акцента наћи кратак силазни акценат:

кӓзан, жӥвот, сирӧма, сёстра, гу̀ма, кавӓна, планйна, равнйца, вретёно.

Све поменуто не би било толико необично да се у грађи не наилази на исте ове лексеме, само са другачијим акценатским ликом у неким од косих падежа:

планйне̄, кава̀но̄м, планйно̄м, куку̀руза .

Стога се чини оправданим поставити питање о пореклу и старости ове појаве. Треба нагласити да је и Ђукановић наилазио на облике са очекиваним краткоузлазним ( ) акцентом у појединим падежима, само у много већем обиму, што је и разумљиво с обзиром на количину грађе којом је располагао.

Појава преношења у метатаксичком духу са кратке ултиме на претходни слог двосложних и вишесложних речи није само обележје вичког (драгачевског) говора, већ и многих других штокавских говора, поготово оних који мадӓнт.

${ }^{7}$ Ово не важи за неке сложенице типа пѐтне̄стоднеิвно, као и за стране речи типа ко- 
нису упознати са појавом метатоније. Ово се најбоље да приметити ако се у обзир узму идиоми са старијом акцентуацијом, при чему се пре свега мисли на косовско-ресавске и зетско-рашке говоре. Велики број њих задржао је старо место и квалитет акцента, али са изузетком баш у ситуацији са краткосилазним на ултими превасходно двосложних, а ако за то има услова (краткоћа осталих слогова) и вишесложних речи ${ }^{8}$. Тако, на пример, неки црногорски говори потпуно познају овакву врсту преношења са кратке ултиме и оно је углавном доследно извршено, док их преношење са унутрашњих слогова не одликује у већој мери. Иста је ситуација и у косовско-ресавским говорима. Ипак, овај тип преношења познат је и неким идиомима са новијим типом акцентуације, као што су говор Груже или говори централне Шумадије.

Као што је већ из литературе познато, метатаксичко преношење јавља се у говорима Левча (Симић 1972), Трстеника (Јовић 1968), али и Груже (Стевовић 1969), па и Шумадије (Реметић 1985). Стога се поставља питање да ли се поменута црта у говорима развила под утицајем суседних косовскоресавских говора, или је она аутохтона и само осветљава до сад у литератури непримећену изоглосу. У прилог аутохтоности ове црте иде податак да је она позната одређеној групи говора која у свим осталим ситуацијама има ново преношење, те се одатле може извући једнозначан закључак: сви наведени говори у ствари су повезани и ову црту су развили и пре самог доласка на садашње просторе. Међутим, њихова удаљеност (то највише важи у случају Драгачево-Гружа), као и неке различитости на осталим језичким нивоима не иду у прилог овој тези. Пре ће зато бити случај да је на њих извршен утицај са стране - утицај који, пре свега због компактности становништва које је донела динарска струја није могао продрети даље од ове ионако (неувежбаном уху) тешко приметне црте. У прилог овоме говори ситуација у шумадијским говорима који се налазе у тзв. кановачкој зони ${ }^{9}$, где је већ полако почела слабити компактност динарског становништва и где се оно већ добрано почело мешати са косовско-метохијским струјама. Ту је, у оваквим ситуацијама, настајало тзв. кановачко дужење $\left(\stackrel{\sim}{\sim} \rightarrow{ }^{\prime}\right.$ ). Онде где таквог мешања није било (или га није могло бити у великој мери) овакви резултати су изостали, а наместо њих појавио се наш случај: ${ }^{\prime \prime} \rightarrow$ " $`$. Нема (видљивих) разлога који би условили да се становништво истог порекла (са једне стране у нпр. Старом Влаху, а са друге у Драгачеву, Гружи и делу Шумадије), чије се акценатске особине у великој већини црта подударају, дели на основу преношења са кратке ултиме. Стога би објашњење могло лежати у томе што су ови наши говори једноставно ближи, а тако и подложнији источним утицајима. Томе у прилог иде и једно занимљиво запажање које Петар Ђукановић наводи у својој монографији, у одељку о акцентима, а које, по нашем мишљењу, у потпуности показује

\footnotetext{
${ }^{8}$ О овоме детаљније у: Пешикан 1965: 25, Симић 1972: 47-48, Јовић 1968: 23.

${ }^{9}$ B. мапе у Реметић 1985: 3, 42, 46.
} 
да је реч о увозној црти, насталој тек након досељавања становништва на ове терене и уједначавања језичког израза на многим нивоима. Наиме, Ђукановић каже како „двосложне речи са краткосилазним акцентом и кратком ултимом (жёна, јёзик), које у стандардној прозодији имају краткоузлазни ( ) акценат, не познају преношење на проклитику" (1995: 109). Он ту наводи примере попут:

у вӧди, у слйжби, у сёлу, на зёмљи.

Они могу послужити као доказ да је краткосилазни акценат на овом месту новина која се развила тек касније и у додиру са суседима, јер овај говор иначе познаје (и то у приличној мери) преношење новијег типа на проклитику. Како за њега овде постоје услови, а није извршено (као што се десило у осталим

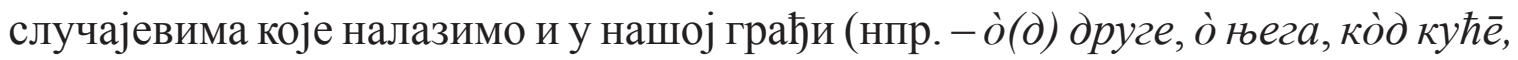
седа̀м-осам...), то значи да се ове речи и даље понашају као да се у њима налази краткоузлазни акценат, те тако ни не постоји разлог због ког би се место акцента мењало. До овакве ситуације могло је доћи из више разлога, а овом приликом осврнућемо се на два: једноставно, мала разлика, која је практично на први поглед (слушање) и неухватљива, условила је да се под суседним утицајем ова црта поткраде и уђе у говор Драгачеваца (а тако и становника Виче), Гружанаца и (понеких) Шумадинаца. Други разлог (у неку руку можда и комплементаран првом) јесте можда то што се корен овакве појаве може наћи (као што је то нпр. случај са оваквим паралелизмима у околини Дубровника, Цавтату или Конавлима) у некој врсти алотоничности новонасталог акцента, па он у појединим случајевима има као резултат дугоузлазни ('), понекад краткосилазни ("), а сви се они понашају као и онај тон који би ту требало да се нађе - краткоузлазни (' ) акценат. ${ }^{10}$ Такође, треба обратити пажњу да зону са појавом метатаксичког преношења, по правилу, прати зона са кановачким акцентом. Која и каква веза стоји између две појаве, питање је на које би једног дана можда најбоље могла одговорити експериментална фонетика.

2.2. Кановачко дужење. Како је кановачко дужење било присутно у једном делу излагања о метатаксичком преношењу акцента са кратке ултиме на кратак претходни слог двосложних и неких вишесложних речи, можда би понајбоље било на овом месту рећи још нешто о тој појави. Кановачко дужење као производ преношења у горе описиваној ситуацији (некадашњи " тип) има дугоузлазни акценат и најсвојственије је (што се предела блиских Драгачеву, а тако и Вичи, тиче) говорима централне Шумадије ${ }^{11}$. У тим пределима, највероватније настало као производ додира са косовско-метохијском струјом ${ }^{12}$,

${ }^{10}$ Опширно о овом проблему в. у Каповић 2015: 671-734, нарочито 692-698.

${ }^{11}$ В. Реметић 1985: 40-53.

${ }^{12} \mathrm{O}$ кановачком дужењу писао је и Александар Белић и притом изнео своју теорију о настанку ове појаве. (Белић 2000: 33). 
оно се може наћи и у Драгачеву (Ђукановић 1995: 91-93), али у веома малој мери. С обзиром на то да је у Драгачеву преовладао тип ${ }^{\sim}{ }^{\rightarrow} \rightarrow$ " , , ова се црта може сматрати резултатом наноса из поменутих говора. У Вичи смо на пример кановачког дужења наишли само у једном случају, и то при преносу акцента на проклитику: ý üen.

3. Преношење акцената на проклитику. Преношење акцената на проклитику само је један од радикалнијих облика новог преношења које је захватило поједине новоштокавске говоре, а као процес најбоље је видљиво у говорима источнохерцеговачког говорног типа. С обзиром на то да су, као што смо већ нагласили, сви становници Виче (као и већина Драгачеваца) дошли из јужних предела и с обзиром на то да њихов говор то у потпуности потврђује својим јединством ${ }^{13}$, осврнућемо се на данашње стање ове особине и у нама доступној грађи.

3.1. Ново преношење на проклитику. Преношење акцената на проклитику производ је радикалне метатоније, при чијем се деловању и проклитика испред самосталне речи сматра делом једне јединствене акценатске речи. Том приликом, ради ликвидације силазног слога унутар (акценатске) речи, нагласак се помера за један слог ка почетку, добијајући притом узлазну интонацију. На његовом некадашњем месту остаће или кратак (уколико је акценат био краткосилазни) или дуг вокал (у случају да је акценат на њему био дугосилазни). Углавном, оваква преношења су присутна у негацији (нпр. нѐ смијем, нѐ треба), као и при додиру самосталних речи са речцама или

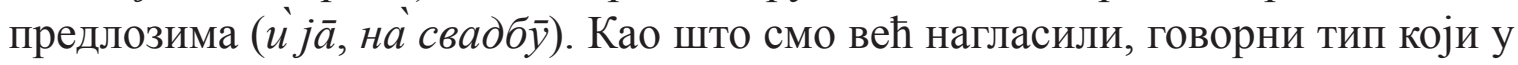
највећој мери баштини ову особину јесте источнохерцеговачки, али у мањој мери и шумадијско-војвођански (мада се највише примећује у додиру ових говора са областима насељеним динарском струјом - в. пример колубарског говора у Пецоㅜ 1980: 48).

У Вичи, будући да је све становништво овог села динарског порекла, било је и очекивано наћи ову црту. У говору нашег информатора, она се прилично често појављивала. Међутим, мора се нагласити да је поред уобичајеног преношења примећен и одређен број ситуација у којима се оно није извршило, иако су за то постојали потребни услови. У наставку ће зато бити изнета већина примера из грађе и, у складу са бројем (не)преношења и ситуација у којима се она (не) појављују, дата одрећена врста закључка.

Преношења су у нашем материјалу извршена у следећим примерима:

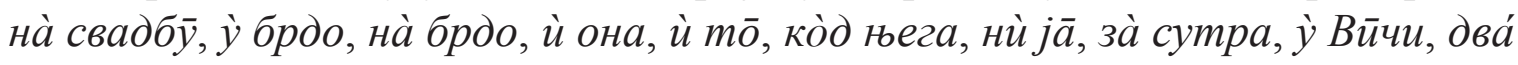

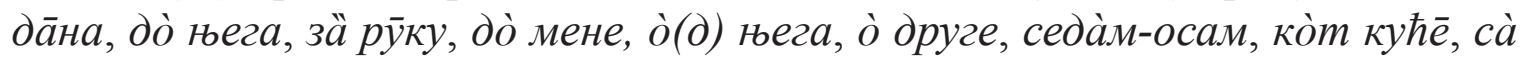

${ }^{13}$ „Говор испитиваног подручја је изједначен: нема ниједне изоглосе која би делила терен.” (Ђукановић 1995: 16). 


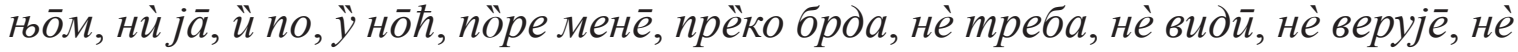
може̄, нѐ да̄, нѐ смије, нѐ смём, нѐ смијем, нё зна̄м.

Пак, у овим ситуацијама, иако су за то постојали услови, преношења није било: од мёда, у Бӓғииу, и ту, до њёга, о свӓдби, преко бёда, у свйјет, у Виิчи, триิ даิна, пред шкӧло̄м, за шљиивуу.

И површно гледајући, да се утврдити како претеже број примера у којима је акценат пренесен (тачније речено однос је 32:11). Притом, треба имати у виду да нису наведени сви примери са негацијом, а ту изузетака практично и нема: у овој категорији пренос се најбоље држи и колебања не постоје. Са друге стране, прве назнаке несигурности могу се видети при додиру са предлозима и речцама. Иако и ту јесте видљива бројчана надмоћ образовања са преношењем, наилази се на примере: од мёда, у Бӓнииу, пред шкӧло̄м, за шлийву. Посебно је значајно уочити да неки формално исти спојеви у једном тренутку имају пренесени облик, док у другом тренутку такво нешто изостаје:

ỳ Вйчи : у Вйчи, до̀ њега : до њёга; прёко брда : преко бёда.

У ову се групу могу још уврстити и:

на̀ свадбӯ : о свӓдби; два́ да̄на: трй да̂на.

Све наведено значи да су се неки од ових облика почели равноправно употребљавати, а наговештај драстичнијих промена (као нпр. код примера који немају варијанту са преношењем) се може видети у ситуацијама где превагу односе образовања без повлачења акцента.

Зато се сада поставља питање: шта све ови подаци поручују и који је узрок за престанак преношења? Насупрот претходном одељку о преношењу акцента са ултиме (в. горе), за објашњење оваквих појава ипак не треба ићи сувише далеко. Такав се закључак намеће када се има у обзиру који су говори суседни вичком (тј. драгачевском). Са источне стране, мада довољно далеко да би извршио јачи утицај и на овом пољу, налази се косовско-ресавски говорни тип, а са северних страна на говоре Драгачева належу шумадијско-војвођански говори, као и градски говор Чачка. И један и други познају преношења у мањој мери (то нарочито важи за источне суседе, радикалне у том погледу). И док се косовско-ресавски говори могу лако одбацити као могуће надахнуће овој појави, то је мало теже учинити са шумадијско-војвођанским говорима. У првом реду, то је тако због приличне блискости ових говора (ако ништа друго, оба познају новију акцентуацију - зато косовско-ресавски говори и бивају одбачени), а у другом може бити због утицаја говорне речи путем средстава информисања (сличне закључке извео је и Петар Ђукановић). Дакле, решење се налази у не баш доследном преношењу у шумадијским говорима, на које такође могу утицати говори Војводине (који са Шумадијом и чине повезанију целину), али и највећег центра Београда. Они опет као такви утичу на Драгачево, како непосредно, тако и посредно, преко градске средине као што је Чачак. 
Упркос свему наведеном, преношење је још увек прилично жив процес. Ако ништа друго, то говори број примера у односу $3: 1$ у корист промене места акцента на проклитику. Притом, ваља додати да се овде може наићи на веома лепе примере, у којима се чувају неке типичне одлике драгачевске акцентуације, које нису претерано познате околним говорима. То је, на пример, преношење у облицима са бројевима (в. два́ да̄на, седа̀м-осам), као и преношење акцента на проклитику испред заменица које у стандардном језику (али и у већини новијих типова) имају краткоузлазни акценат - мѐне, њѐzа ${ }^{14}$. У Вичи, ове заменице имају облике мёне, њёга, па ће тако оне, при додиру са нпр. предлозима, предати свој акценат: ко̀ њега, ò(д) њега, до̀ мене, до̀ њега.

3.2. Старо преношење на проклитику. При крају овог дела ваља нагласити да су до сада у обзир узимани само случајеви новог, метатонијског преноса, али треба рећи да је, поред тога, још увек присутно и старо пре-

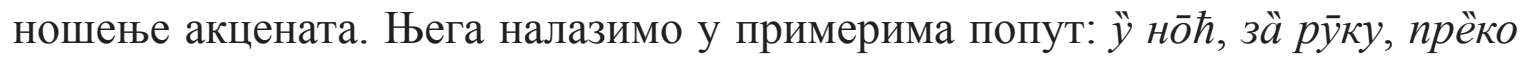
брда, пӧре мене.

Док се код једносложних предлога нагласак преноси управо на тај једини слог, и то у форми краткосилазног акцента, у двосложним речима долази до прескакања слога који се налази одмах до акцентогене речи и преноси се на први слог предлога (пӧре мене). Из овог примера такође се да закључити како је краткосилазни акценат у заменици мёне стара појава, чим је успео да буде померен док је још важио закон метатаксичког преноса.

4. Постакценатске дужине. Вички говор спада у ону групу говора српског језика која чува дуге ненаглашене слогове. Ипак, овој констатацији ваља прићи са опрезом, јер њу не ваља проширити на све такве слогове. Наиме, док су постакценатске дужине у доброј мери и даље присутне у говору села, дотле у њему не постоји ниједан траг предакиенатских дужина. Узевши у обзир природу акцентуације овог идиома, то се могло и очекивати. Све предакценатске дужине ликвидиране су при појави повлачења силазних акцената ка почетку речи за један слог, из чега следи да је добар део дугозлазних акцената тог порекла. Тако је нпр: би́ло < бйлӧ, бо́лниия < борлнйца, озе́беш < озеббеิш, при́чају < прйча̄jӯ, ли́вница < лйвнййа.

Враћајући се опет на постакценатске дужине, може се рећи да је приличан део њих настао процесом супротним од наведеног: док је у претходном случају било $^{-\vee}$ или $^{-}{ }^{-} \rightarrow{ }^{\prime}{ }^{\prime}$ или ${ }^{-}$, , сада ће повлачење акцента на претходни слог некада слогове под дугосилазним акцентом остављати без нагласка -

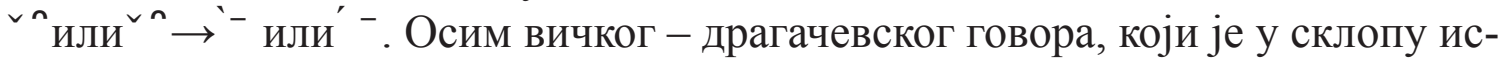
точнохерцеговачког говорног типа, постакценатске дужине чувају сви говори са млађом акцентуацијом (шумадијско-војвођански - у мањој мери, млађи

${ }^{14}$ Истина, стандард допушта и облике са краткосилазним акцентом (мёне, ґеега), али то првобитно није био случај. 
икавски), али и неки говори са старијим прозодијским особинама (зетскорашки). Оне се могу наћи у речима готово сваке реченице и провлаче се кроз све врсте речи:

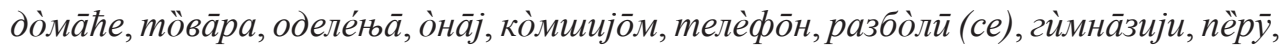

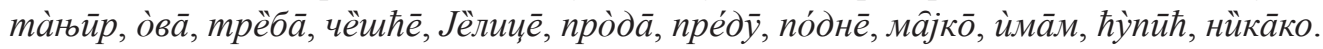

4.1. Губљење постакценатских дужина. Упркос оваквом стању, једна од новијих појава у свим говорима са новијом акцентуацијом јесте губљење постакценатских дужина у појединим позицијама и под одређеним условима. То је најлакше приметити у примерима у којима би требало да се нађе неколико узастопних дужина. Најтипичнија категорија, у којој најпре треба тражити примере губљења узастопних дужина, јесте генитив множине свих родова, који увек поред дужине на последњем слогу има и дуг вокал ближи

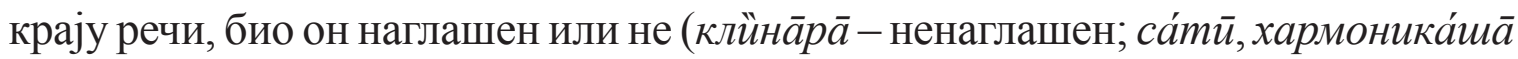
- наглашен). У овој категорији чак и стандард допушта изостављање једне

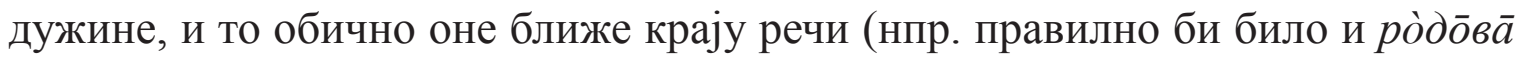

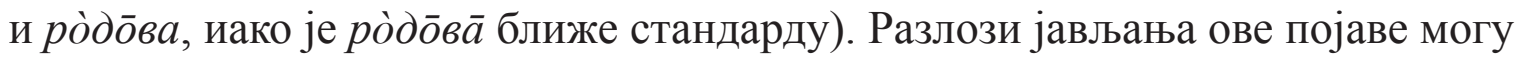
се потражити на више места. Прво, то може бити у складу са општештокавском тенденцијом отклањања дужина од краја речи, а приметно је да се ни шумадијско-војвођански не може похвалити редовним чувањем дугих слогова. Друго објашњење би могло лежати у принципу језичке економије (ово опет треба везати за утицаје из градских центара, где је помињани принцип најпотребнији и најприсутнији). Све ово, дакле, значи да губљење дужина и у овом говору може имати више узрока: то могу бити утицаји суседних говора, а може евентуално бити и аутохтона црта или оба заједно, наравно, не заборављајући ни језичку економију. Међутим, како је приметно да, идући јужније (југозападније), дијалекти нашег језика ревносије чувају дужине, јасно је како је овде у питању северни утицај додатно подстакнут близином већег градског центра - Чачка. У складу с реченим може се закључити да је говор, Виче у великој мери изгубио способност чувања двоструких дужина, а то се потврђује када се у обзир узму подаци из грађе:

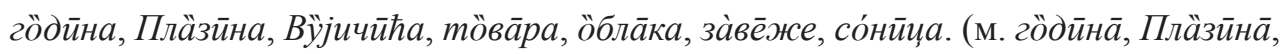

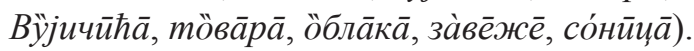

У материјалу није нађен практично ниједан пример који би одговарао типу са двоструким дужинама и акцентом на одговарајућем вокалу у речи.

Али док је губљење узастопних, квантитетом обележених вокала можда било и лако предвидети и објаснити, губљења дужина јављала су се и на другим местима, на местима која не би могла бити објашњена поменутим аргументима. Примећено је да се у појединим позицијама и након неких акцената дужине знатно слабије чувају него што је то случај у осталим ситуацијама. Из тог 
разлога, приложићемо један краћи преглед, који као параметре узима врсту акцента, као и отвореност/затвореност слога на ком се дужина налази.

Затворен последњи слог:

1) Краткосилазни акценат (") након ког:

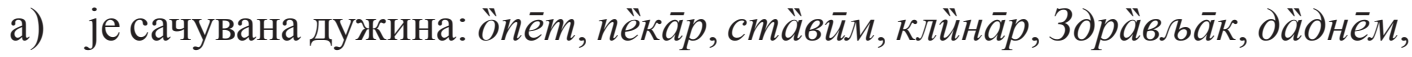
ӧдём, ӱзмём, пӧјдемм, стӧларр;

б) није сачувана дужина: у материјалу нема примера;

2) Краткоузлазни акценат ( ' )након ког:

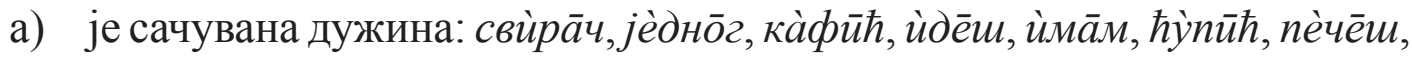
тйчйш, нѐмо̄j, ко̀мпйр, прттйм;

б) није сачувана дужина: у материјалу нема примера;

3) Дугосилазни акценат $\left(^{n}\right)$ након ког:

a) је сачувана дужина: ја̂вйш;

б) није сачувана дужина: ра̂диш, гүิраш, прйђем, (x) оิдај, пођђем, креิнем, паิмтиш;

4) Дугоузлазни акценат (' ) након ког:

a) је сачувана дужина: сту́че̄щ, пи́зӣu;

б) није сачувана дужина: обна́родујеш.

Отворен последњи слог:

1) Краткосилазни акценат ( " ) након ког:

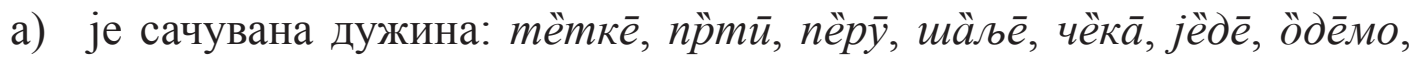

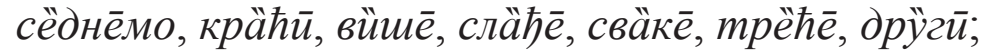

б) није сачувана дужина: пӧсле, нёки, с'ёдне, Жӥвичке, сӥпају;

2) Краткоузлазни акценат (') након ког:

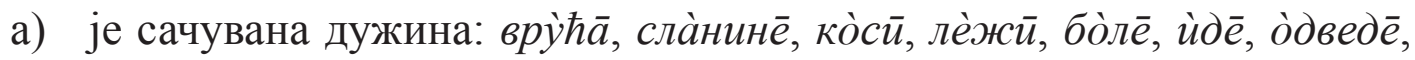

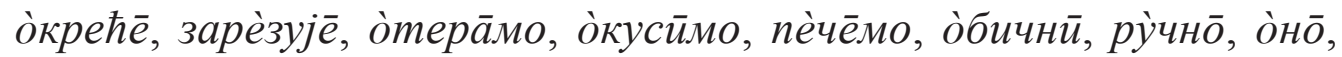
$m a ̀ k \bar{a}$;

б) није сачувана дужина: бѝjame, ѝзвади, пију̀йкају;

3) Дугосилазни акценат ( ${ }^{\wedge}$ ) након ког:

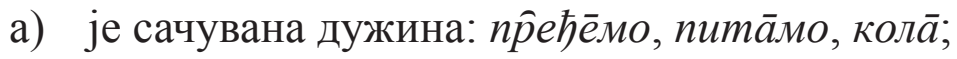

б) није сачувана дужина: киิла, даิна, са̂та, приิча, коิшта, ка̂же, свиิра, скиิда, поेђемо, дођемо, враิтимо, (x)ồа, пуेсте, жиิва (придеви одр. вида), Горюьи (Дубац);

4) Дугоузлазни акценат (") након ког:

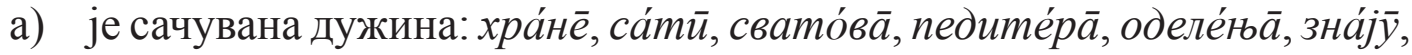

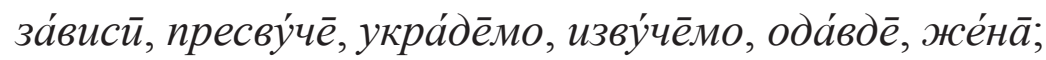

б) није сачувана дужина: гу́рају, при́чају. 
Да се након овог прегледа закључити:

1) Дужине се најбоље чувају након кратких акцената (независно од тога да ли је слог са дужином отворен или затворен), и то боље након узлазних него након силазних - мада је разлика незнатна;

2) Дужине се најдоследније губе након дугосилазног ( ${ }^{\wedge}$ ) акцента (опет независно од отворености/затворености крајњег слога);

3) Дужине су подложније губљењу на крајњим отвореним слоговима него на крајњим затвореним слоговима;

4) Након дугоузлазног акцента, дужине се доследно чувају ако се налазе на суседном слогу; уколико то није случај, дужине се губе.

Поредећи ситуацију у вичком говору (а њега посматрамо као један од изворно источнохерцеговачких идиома у којима се дужине доследније чувају) са ситуацијом у шумадијско-војвођанском говорном типу, што се дугих неакцентованих слогова тиче, долази до поклапања у одређеним појавама. Подудара се наша тачка 3) са констатацијом Павла Ивића да су дужине на отвореном последњем слогу мање отпорне од оних на затвореном (Ивић 2001: 95-96). Такође, тачка 2) делимично потврђује да је нестајање дужина олакшано, ако је у њиховом суседству дуги акценат - за дугосилазни се то и овде у свим приликама догађа; код дугоузлазног улогу игра и удаљеност од дужине. Ови подаци јасно показују одакле ове црте стижу и на који начин оне постепено освајају терен, не би ли у једном тренутку избрисале већину разлика и тако га дијалекатски изнивелисале. Главни је правац деловања ове изоглосе север-југ, при чему ваља имати у виду да је и у самом шумадијско-војвођанском типу источнија област склонија овој особини од западне (утицај косовко-ресавског?). Ипак, треба нагласити да се постакценатске дужине још увек прилично добро чувају и да, поред преношења на проклитику, представљају један разлог више зашто ове говоре при класификацији треба убрајати у источнохерцеговачки говорни тип.

5. Закључак. Све наведено може послужити при општој класификацији овога говора. С једне стране, карактеристични четвороакценатски систем, прилично доследно чување дужина, те углавном живо преношење акцента на проклитику, сведоче да је у питању један драгачевски идиом у склопу источнохерцеговачког говорног типа. Ипак, страни утицаји, а ту се пре свега мисли на метатаксичко преношење акцента са кратке ултиме, везују овај говор за одређене шумадијске идиоме (нпр. гружански или шумадијски), који су и сами производ утицаја косовско-ресавског говорног типа. Индикативно у овом смислу, такође, јесте све учесталије губљење постакценатских дужина, као и ограничени изостанак преношења акцента на проклитику. Стога се из поменутог може закључити да ће у будућности посредством ових тенденција, на терен Драгачева, а тако и Виче, стизати, све јаче и упорније, новине са севера, 
претећи да тако дијалекатски изнивелишу подручје које, томе упркос, за сада успева да задржи самосвојност.

\section{ЛИТЕРАТУРА}

Белић 2000: А. Белић, О дијалектима, Београд: Завод за уџбенике и наставна средства.

Ђукановић 1995: П. Ђукановић, Говор Драгачева, Београд: Институт за српски језик САНУ.

Ердељановић 1902: Ј. Ердељановић, Доње Драгачево, Српски етнографски зборник, IV: 1-224.

Ивић 2001: П. Ивић, Дијалектологија српскохрватског језика. Увод и штокавско наречје, Сремски Карловци - Нови Сад: Издавачка књижарница Зорана Стојановића.

Јовановић 1908: К. Јовановић, Горње Драгачево, Српски етнографски зборник, XI: $311-407$.

Јовић 1968: Д. Јовић, Трстенички говор, Српски дијалектолошки зборник, XVII: $1-241$.

Каповић 2015: M. Kapović, Povijest hrvatske akcentuacije, Zagreb: Matica hrvatska.

Марковић 2011: С. 3. Марковић, Говор Ужичке Црне Горе, Српски дијалектолошки зборник, LVIII: 337-672.

Пешикан 1965: М. Пешикан, Староцрногорски средњокатунски и љешански говори, Српски дијалектолошки зборник, XV: 1-294.

Реметић 1985: С. Реметић, Говори централне Шумадије, Српски дијалектолошки зборник, XXXI: 1-555.

Симић 1972: Р. Симић, Левачки говор, Српски дијалектолошки зборник, XIX: $1-619$.

Стевовић 1969: И. Стевовић, Шумадијски говор у Гружи са особитим освртом на акценте, Српски дијалектолошки зборник, XVIII: 401-635.

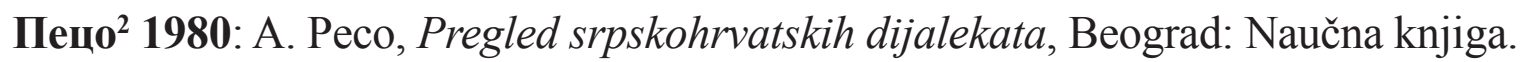




\title{
THE BASIC ACCENTUAL FEATURES OF VIČA IDIOM
}

\begin{abstract}
Summary
Presented within this piece of work are accent features of Viča village (Dragačevo) based on analysis of an audio recording of an autochthonous speaker from the aforementioned area. Following the introduction, which details the geographic position, ethnological and linguistic research of the area and goals of the research, speech is, by the accentual parameters, localised on a dialect map of Serbian language. Apart from the baselines which indicate that it belongs to a type of Eastern Herzegovinian dialect in Serbia, it should be mentioned that it contains some specifics which bring the idiom closer to Sumadija-Vojvodina dialect. Among specific accent traits is the metataxic transfer of accent from ultima to penultima, which came to be as a consequence of a newer application from Šumadija-Vojvodina dialect which relies on Kosovo-Resavian and Smederevo-Vršac idioms, which in turn brings the Viča idiom closer to older accentuation types. This, also, opens up the question of alotonicity regarding the transfer of short accents. The accent features of Viča (and compete Dragačevo area) dialect belong to Eastern Herzegovinian dialect, but, they contain many adopted traits which require the following of its development.
\end{abstract}

Key words: Viča, Dragačevo, dialectology, Eastern Heryegovinian, accentual system, metataxic transfer.

Đorđe M. Genović 